\title{
Pollution and the Price of Power
}

\author{
Donald N. Dewees \\ Department of Economics \\ Faculty of Law \\ University of Toronto \\ 150 St George St. \\ Toronto, ON \\ M5S 3G7 \\ Department of Economics Working Paper \\ DRAFT \\ July 18, 2006
}

(C) Donald N. Dewees. All rights reserved. Short sections may be quoted without explicit permission, provided that full credit, including (C) notice, is given to the source.

I would like to thank Noureen Shah for her work as research assistant on this project. 


\begin{abstract}
Recent benefit-cost studies have shown that the marginal benefits from controlling conventional air emissions from coal-fired electric utility power plants in the US exceed marginal costs of pollution control. Moreover existing and proposed regulations ignore harm caused by the emission of greenhouse gases and harm caused in Canada. This means that electricity prices are too low wherever coal is the predominant fuel. However the same studies suggest that the mis-pricing of electricity is $4 \%$ or less. This paper will argue that in some regions of the US the wholesale price of electricity should be increased by up to $50 \%$, if all externalities are to be included in the price. Getting the environmental price right could reduce pollution levels, increase energy conservation, and lead to wiser choices of new generation technology.

JEL Classification: L94, Q40, Q42, Q50, Q51, Q53, Q58
\end{abstract}

Keywords: electricity, electricity price, air pollution, emissions trading, CAIR 


\section{Introduction}

Recent studies have shown that reducing air pollution emissions from fossil-fuelled electricity generation units would give rise to large benefits, mostly from improved public health. Banzhaf, Burtraw and Palmer (2004, p. 318) found that the optimal national average effluent charges for SO2 and NOX emissions in the US are $\$ 3,500$ and $\$ 1,100$ respectively, which would lead to an $89 \%$ reduction of $\mathrm{SO} 2$, a $70 \%$ reduction of NOX, and a $5 \%$ reduction in $\mathrm{CO} 2$ nationwide in 2010 compared to a baseline without the tax. At 2004 average US coal plant emission rates, these damage values mean that coal causes external harm worth about $\$ 26$ per megawatt-hour (MWh). While the US EPA (2005a, p. 2-4) found that the benefits of its Clean Air Interstate Rule (CAIR), which will substantially reduce utility emissions in the eastern half of the US, greatly exceed the total benefits, Palmer, Burtraw and Shih (2005, p. 77) concluded that limits more stringent than CAIR were justified. A recent analysis for the Government of Ontario reports that reducing the output and emissions of the average Ontario coal-fired generating station would reduce health damages by as much as CDN $\$ 113 / \mathrm{MWh}$ (or US $\$ 96$, assuming that CDN $\$ 1=$ US $\$ 0.85$ ). (DSS, 2005, p. 29.) This is almost five times the US average above because of much higher estimated health effects and a higher value of life. The Ontario government has committed to closing the coal-fired generating stations. ${ }^{1}$

Palmer, Burtraw and Shih $(2005, \mathrm{pp} .36,37)$ found that implementing CAIR would not significantly raise the price of electricity in 2010 or 2020, while Banzhaf, Burtraw and Palmer (2004, p. 333) found that efficient effluent charges for SO2 and NOX would raise the average US retail price in 2010 by only $4 \%$. The EPA finds that CAIR would raise retail electricity prices in the 26-state CAIR region by $2 \%$ in $2010,2.7 \%$ in 2015 and $1.8 \%$ in 2020. (US EPA, 2005a, p. 7-14.) The largest price increase, $5.9 \%$ in 2015, is in the ECAR electricity control region which has a large fraction of coal generation and the third-lowest price in the 2015 base case. The EPA base case itself assumes compliance with pre-CAIR regulations which will involve significant emission reductions from 2004 levels and thus some additional costs.

While the recent simulations are excellent, none of them has calculated the impact on the electricity price of an efficient regional effluent charge for states just south of the Great Lakes where coal generates $85 \%$ of the electricity and where Canadian benefits are important. See Table 1. This paper will argue that electricity was under-priced by as much as $\$ 50 / \mathrm{MWh}$ in the ECAR control region in 2004 and will remain under-priced by 2015 even with CAIR. The reasons are several. Electricity prices today include only a fraction of the damage costs from discharging conventional pollutants because allowance prices are less than damage costs in the ECAR region and because regulated utility prices do not include the opportunity cost of allowances. Even CAIR does not achieve optimal emission reductions in this region. Most of the studies ignore global warming, yet analyses of GHG damages have suggested benefits from near-term GHG reductions of as much as $\$ 10 / \mathrm{MWh}$ for coal-fired generation. The US analysis

\footnotetext{
${ }^{1}$ News Release, 15 June, 2005, McGuinty Government Unveils Bold Plan to Clean Up Ontario's Air, Ontario Ministry of Energy. http://www.energy.gov.on.ca/index.cfm?fuseaction=english.news\&body=yes\&news_id=100 . Viewed April 13, 2006.

Pollution and the Price of Power, DRAFT 1

18 July, 2006
} 
ignores any benefits that might accrue in Canada, yet half of the air pollution in southern Ontario blows in from the Ohio valley. (OCAA, 2005, p. 24.)

We will use the ECAR states, excluding those only fractionally in ECAR, to study the price effects that might arise from imposing an efficient effluent charge in a heavily populated coal-burning region. ${ }^{2}$ We call these states "ECAR Lite." We will calculate two price adjustments for coal and gas-fired power plants, assuming that generators should pay effluent charges equal to the external harm that they cause:

- By how much did the 2004 wholesale price fall short of private plus social cost because of the marginal external harm from criteria pollutants, the Canada adjustment and $\mathrm{CO} 2$ ?

- By how much does the EPA's forecast 2015 wholesale price with the CAIR program fall short of marginal social cost because of the marginal external harm from criteria pollutants, the Canada adjustment and CO2, given forecast 2015 emission rates?

We will make two comparisons: one for a competitive plant, another for a plant subject to rate regulation. The difference is that the former will include allowance prices in its cost while the latter will not, since utilities are not net buyers of allowances.

\section{Efficient Pricing of Electricity}

Basic price theory says that when price equals marginal cost (MC), consumer surplus and producer surplus are maximised if there are no externalities. (Varian, 1990, ch. 28.) Therefore marginal cost pricing should achieve efficient electricity production and consumption in the absence of externalities. (Joskow and Schmalensee, 1983, p. 81.) Where production causes harm to another party, the efficient level of production is achieved if the marginal external cost is added to the marginal private cost to set the price to which the consumer will then equate to her value. (Varian, 1990, ch. 30.) If consumers face a price less than this marginal cost, there is a welfare loss arising from excess production and consumption.

Joskow and Schmalensee (1983, p. 88) note that wholesale and retail power prices "are currently not generally based on marginal cost pricing principles." Regulated rates for most consumers are designed to cover average total costs (ATC), not to represent marginal private costs. When demand is high relative to capacity, $\mathrm{MC}>\mathrm{AC}$ and the regulated price is too low. When demand is low relative to capacity, $\mathrm{MC}<\mathrm{AC}$ and the regulated price is too high. More important for our purposes, utility prices do not include the cost of environmental harm arising from generation. While environmental regulations will force most utilities to control some of their air emissions, and the costs of those controls will be paid for by consumers, the utility will not pay for the harm caused by the remaining emissions. Where this un-priced harm is substantial, electricity is substantially under-priced.

\footnotetext{
${ }^{2}$ ECAR includes Michigan, Indiana, Ohio, Kentucky, West Virginia, part of western Pennsylvania, and the western end of Virginia. We exclude Virginia and Pennsylvania.

Pollution and the Price of Power, DRAFT 2

18 July, 2006
} 
Utility prices would be corrected for environmental harm if every utility were required to pay for the damage that its emissions cause. Nowhere in North America is this required. However in Ontario and the US some air emissions are controlled by cap-and-trade programs which distribute free allowances to polluters and require them to surrender one allowance for each ton of pollution discharged. The cap forces utilities to limit their total pollution, and in equilibrium the allowance price represents the marginal cost of control. The discharge of a ton of pollution thus imposes an opportunity cost on the utility. One might expect that these capand-trade programs would cause the pollution damage to be reflected in the price of power. In practice, only a small fraction of the external cost is internalised.

A regulated utility may set rates that recover reasonable and necessary costs, which would include the net cost of allowances: the cost of allowances purchased less the revenue from allowances sold. Since allowances are initially distributed at no cost in the relevant US and Ontario trading programs, the net cost of allowances must be zero for the average utility. Thus while emissions trading programs share many of the efficiency advantages of effluent charges, in the case of regulated utilities they do not increase the product price in the same way as an effluent charge. On average they do not increase it at all.

A generator in a competitive jurisdiction behaves differently. When bidding its electricity it will include the opportunity cost of necessary allowances in its calculation of the marginal cost of generation of a MWh since the allowance may be bought or sold at the market price. The price of allowances is therefore automatically imbedded in the competitive electricity price. If the cap has been set optimally, the allowance price should equal the damage cost. If the cap is too lenient, the allowance price falls short of the damage cost and the electricity price does not cover full social costs.

Joskow $(2006$, pp. 6, 7, 21) concludes that there is effective wholesale competition in much of the US northeast and retail competition for all customers from Michigan and Ohio eastward. Palmer and Burtraw (2005, p. 877) assume that electricity prices are set competitively in five control regions representing about 19 states in the northeast quarter of the country, an area bounded on the west by Wisconsin and Illinois and on the south by Kentucky and Virginia, plus Texas. They further assume that large consumers in those states face the market price. However even those states that have a competitive wholesale market often do not often charge small and medium size consumers the competitive price. Many of those consumers pay regulated rates. Ontario initially passed the spot price to most consumers when the market opened, but after six months of high prices the government replaced the spot price for small and medium consumers with a fixed (low) price and then with a regulated price that has on average been below the spot price. (Dewees, 2006, p. 7.)

Some public utility commissions have considered "adders" to represent environmental harm, but most of these would have affected the choice of new generating units to build or the dispatch of units, not the price. (Burtraw, Palmer and Krupnik, 1997.) 
We calculate the environmental under-pricing of electricity as follows. Assume a jurisdiction in which there are $\mathrm{G}$ types of generation unit, with all units of a type being identical. Let:

$X_{i}=$ marginal harm from the discharge of one ton of pollutant $i$, for up to $N$ pollutants;

$E_{i j}=$ the rate of discharge of pollutant $i$ from a source of type $j$, for up to G types, in tons/MWh;

$P_{i}=$ price of an allowance to discharge one ton of pollutant $i$;

$H_{j}=$ harm caused by generating one MWh of electricity from source type $j$;

$U_{j}=$ the extent to which electricity generated by a source of type $j$ is under-priced. The external harm caused by generating one more MWh of electricity from source type $j$ is:

$$
H_{j}=\sum_{i=1}^{N} E_{i j} * X_{i} \$ / \mathrm{MWh}
$$

In a regulated jurisdiction with only type $j$ generators, under-pricing equals the sum of the external costs of each pollutant emitted by generating one more MWh from a particular fuel, given its emission rates, that is, $H_{j}$. In a competitive jurisdiction, under-pricing equals the sum of external costs for each pollutant emitted by generating one more MWh from a particular fuel less the market price of allowances surrendered:

$$
U_{j}=\sum_{i=1}^{N} E_{i j} *\left(X_{i}-P_{i}\right) \quad \$ / \mathrm{MWh}
$$

If the price of allowances $P_{i}$ equalled the external harm, the under-pricing would be zero.

Suppose that the jurisdiction has several types of generation unit. In a regulated market, where each type of unit generates a share $\alpha_{j}$ of total MWh of electricity, the extent to which the regulated market price $U_{R}$ falls short of the efficient price is the weighted average of the underpricing of power from each type of unit:

$$
U_{R}=\sum_{j=1}^{G} \alpha_{j} H_{j} \quad \$ / \mathrm{MWh}
$$

In a competitive market, where each type of generation unit is the price-setting type for share $\beta_{j}$ of the total MWh of electricity generated, the average competitive market price falls short of the efficient price in proportion to the fraction of power sold when each type of unit is the pricesetter:

$$
U_{C}=\sum_{j=1}^{G} \beta_{j} H_{j} \quad \$ / \mathrm{MWh}
$$

These calculations assume that within each type of generation units all units are identical, which is sufficiently realistic for the approximate calculations undertaken here.

\section{The Marginal Harm from Electricity Generation}

The two studies by researchers at Resources for the Future model the electric utility sector in considerable detail, using plant data on heat rates, emission rates and costs to determine the mix of generation that would be used by cost-minimising utilities under varying regulatory assumptions. They assume that wholesale electricity prices are based on average cost in Pollution and the Price of Power, DRAFT 4

18 July, 2006 
regulated jurisdictions and on marginal cost in competitive jurisdictions. Costs include the cost of pollution control and the cost of effluent charges or the opportunity cost of emission allowances. They model 13 regions, four daily time periods and three seasons, determining the electricity market equilibrium supply and demand in each. (Banzhaf, Burtraw and Palmer, 2004, pp. 321-323.) The electricity model produces emissions which an air dispersion model distributes and a damage model values. Both studies use a value of statistical life equal to \$2.25 million (US 1999). Both studies ignore benefits in Canada and benefits from controlling GHG.

Banzhaf, Burtraw and Palmer (2004, p. 318) find that the benefits of reducing SO2 emissions in the US are worth between $\$ 1,800$ and $\$ 4,700$ per short ton while NOX emissions are worth from $\$ 700$ to $\$ 1,200$ per short ton. Translating these into national average optimal effluent charges of $\$ 3,500$ and $\$ 1,100$ respectively would lead to an $89 \%$ reduction of $\mathrm{SO} 2$, a $70 \%$ reduction of NOX, and a 5\% reduction in $\mathrm{CO} 2$ nationwide. They compute pollution reduction benefits on a regional basis as well, finding benefits of $\$ 3,500 /$ ton of SO2 reduction in Indiana, Illinois, Ohio, Pennsylvania, and New York and still higher benefits in another six states, while benefits are low in western states other than California. (p. 329.)

Palmer, Burtraw, Shih (2005, p. 76) find that the national benefits of reducing SO2, NOX and mercury as required by CAIR with seasonal NOX cap and mercury limit outweigh the costs by a factor of four to one. Their lower bound estimate of the benefits of SO2 reduction, $\$ 2,900$ to $\$ 3,100$ per ton are close to triple the forecast 2020 SO2 allowance price of $\$ 1,200$ per ton, suggesting that limits more restrictive than CAIR are justified. (p. 77.)

The EPA's Regulatory Impact Analysis (RIA) for CAIR concludes that by 2015 the health and environmental benefits of CAIR will be valued at $\$ 86.3$ billion to $\$ 101$ billion per year, more than 25 times the cost of compliance which is valued at $\$ 3.07$ billion to $\$ 2.56$ billion per year, using discount rates of $7 \%$ and 3\% respectively. (EPA, 2005a, p. 2-4.) CAIR will cap SO2 and NOX emissions in 28 eastern states and the District of Columbia, ultimately reducing their annual emission rate by $70 \%$ and $60 \%$ respectively, somewhat less than the optimal reductions calculated by Banzhaf, Burtraw and Palmer (2004). The benefits are in comparison with a baseline scenario in which CAIR is not implemented but all pre-existing rules including Title IV of the 1990 CAA are enforced. The benefits consist mostly of health improvements, $90 \%$ of which arise from reductions in premature mortality, with modest contributions from improved visibility. A statistical life is valued at \$5.5 million in 1999 \$US. The study does not include benefits from reduced acid and particulate deposition damage to cultural monuments and other materials, reduced ozone effects on forested ecosystems, and environmental benefits due to reductions of impacts of acidification in lakes While states are free to implement any regulations for any sources to achieve the required reductions, the RIA analysed reductions in emissions from electricity generating stations. Benefits are not estimated separately by region nor by state.

The DSS/RWDI (2005) study for the Government of Ontario analyses the costs and benefits in Ontario (ignoring US benefits) of reducing Ontario air emissions. It reports that reducing the output (and thus emissions) of the average Ontario coal-fired generating station would reduce health-related damages by as much as CDN \$113/MWh (or US \$96, assuming that Pollution and the Price of Power, DRAFT 5 18 July, 2006 
CDN $\$ 1=$ US \$0.85). (DSS, 2005, p. 29.) This is five times the US average benefits reported in the US studies and would justify more dramatic emission reductions, perhaps even justifying the government's plans to close the coal-fired plants by 2009. These values are several times greater than previous health effects estimates because they are based on recent long-term cohort studies of health effects which embody significantly higher exposure-response relationships than the previous literature. (DSS/RWDI, 2005, p. 19.) The assumed value of a statistical life is $\$ 4.18$ million (2004 \$CDN) equal to \$3.55 million US, higher than the RFF studies, but lower than the EPA's value. Benefits of $\mathrm{CO} 2$ reduction are assumed to be either $\$ 10$ or $\$ 15 \mathrm{CDN} /$ tonne. The total damages from coal-fired generation including environmental effects are about $\$ 133 / \mathrm{MWh}$ or $\$ 113$ US. (DSS/RWDI, 2005, p. ii.) We will not rely on the Ontario health effects model since it is relatively recent, but it raises the possibility that the RFF and even the EPA studies may substantially under-value health effects.

The omission of Canada from the US benefit estimates is not easy to correct without the full model simulations. However some idea of the implications may arise from looking at Banzhaf's map of benefits per ton of SO2 (Banzhaf et al., 2004, p. 329). Kentucky, North Carolina, Tennessee, Virginia, and New Jersey all fall in the highest benefit range: $\$ 3,829$ to $\$ 6,062$ per ton. The next tier of states to the north, Illinois, Indiana, Ohio, Pennsylvania, and New York fall in a lower benefit range: $\$ 3,338$ to $\$ 3,688$ per ton of SO2. Michigan and West Virginia have benefits of $\$ 2,795-3,245 /$ ton. The more southerly state benefits are $15 \%$ to $64 \%$ greater. The population density of the second group of states is not significantly less than the first group, so the lower benefits seem likely to be caused by the frequent winds blowing to the northeast and the minimal populations to their north if Canada is ignored. Since the population density of southern Ontario and southwestern Quebec ${ }^{3}$ is similar to that of the adjoining Great Lakes states, it is possible that including Canada in the benefits model would raise the benefits per ton for the ECAR states close to those in the first group of states. We could approximate this adjustment by increasing the SO2 benefits for these three states by $25 \%$. For NOX, there is no benefits map, but we could increase the average benefit of $\$ 1,100$ per ton by the same $25 \%$.

Alternatively, we could assume a perfectly mixed airshed among the ECAR states and southern Canada. If the airshed is mixed, omitting the Canadian portion omits damages proportional to the southern Canadian population divided by the population of ECAR plus southern Canada. In 2004 the ECAR population was 33.77 million; the southern Canadian population was 14.868 million. Adding southern Canada would add $30.57 \%$ to the US damages. This tends to support a Canadian supplement of at least $25 \%$.

The benefits of reducing greenhouse gas emissions have been estimated in several studies in the last decade. Gillingham, Newell and Palmer (2004, pp. 67, 85) reviewed the major empirical studies of the environmental benefits of reduced GHG emissions. These include the IPCC Working Group III contribution to the Second Assessment Report (Pearce et al., 1995), the Third Assessment Report of the IPCC and additional reports including Tol (1999). These estimates depend significantly on assumed discount rates; Tol (1999, p. 69) estimated the

\footnotetext{
${ }^{3}$ We include the Ontario population south of Sudbury and the population of southwestern Quebec: Montreal, Sherbrooke, and Trois Rivieres, a total of 14.868 million in 2004.

Pollution and the Price of Power, DRAFT 6

18 July, 2006
} 
benefits at $\$ 9$ to $\$ 23$ per metric tonne of carbon for real discount rates of 5\% and 3\% respectively. Gillingham, Newell and Palmer find a mean damage estimate of \$30 per metric tonne of carbon discharged, in 2003 US dollars. Since 1 tonne of carbon implies 3.67 tonnes of $\mathrm{CO} 2$, this is equal to $\$ 8.17$ per tonne of $\mathrm{CO} 2$. The US National Commission on Energy Policy (2004, p. 23) surveyed the literature and found benefit values ranging from $\$ 3 /$ tonne to $\$ 19 /$ tonne of CO2.

Another source of evidence on the value of GHG reductions is forecast costs for policies to reduce GHG discharges. A forward market has developed for $\mathrm{CO} 2$ emissions in Europe, as countries prepare for the first Kyoto period, with 2006, 2007 and 2008 allowances for CO2 trading for over $€ 20$ per tonne in late 2005 (Evolution Markets, 2006b), equal to about US $\$ 24 /$ tonne. Canada's Climate Change Plan promises large final emitters that they will not have to pay more than $\mathrm{CDN} \$ 15 /$ tonne of $\mathrm{CO} 2$, suggesting a maximum policy value of such reductions in Canada. (Canada, 2005, p. 2.) In the US, several policy proposals have addressed costs as follows: $\operatorname{NCEP}(2004$, p. 23) caps CO2 allowance prices at \$7/tonne in 2010; the McCain-Lieberman senate bill is forecast to cause CO2 prices of $\$ 9$ to $\$ 16$ in 2010 and $\$ 15$ to $\$ 36$ in 2020 (NCEP, 2004, p. 26); the Regional Greenhouse Gas Initiative (RGGI, 2005) is forecast to cause prices ranging from $\$ 2$ to $\$ 11$ in 2020 .

We will use US $\$ 10$ per metric tonne of $\mathrm{CO} 2$ to represent the benefits for $\mathrm{CO} 2$ reduction. Since coal-fired generating stations emit almost one tonne of $\mathrm{CO} 2$ per $\mathrm{MWh}, \$ 10 \mathrm{CO} 2 \mathrm{implies}$ climate change damage of almost $\$ 10$ per MWh for coal-fired generation. An analysis of the UK electricity industry shows that a price of $\$ 15 /$ tonne $\mathrm{CO} 2$ would raise the price of electricity in the UK by about $€ 6 / \mathrm{MWh}$, or over $20 \%$, in 2015 , given a competitive electricity market. (Neuhof, Grubb and Keats, 2005, p. 20.)

The US Energy Information Administration publishes annual emissions by pollutant, fuel type and state and annual generation by state and fuel type. (US DOE EIA, 2005.) We have used year 2004 state average emission rates for coal and for natural gas and other gases for the ECAR Lite states. A plant-level data set from the EPA reveals that a significant fraction of the natural gas burned in our states is burned in coal plants where it represents less than $1 \%$ of the total fuel. Much of the gas and oil is burned in peaking turbines, which have low efficiency and thus high carbon emissions/MWh. For 2015 we use the EPA's simulations of electricity generation and pollution emissions by state and fuel type, reported in the Regulatory Impact Analysis and its supporting documents. (US EPA, 2005a, b.)

Table 2 summarises the harm caused by pollution discharged from a set of electric generating stations using 2004 discharge rates, assuming a value of $\$ 3,500 /$ ton for SO2 discharge, $\$ 1,100$ per ton for NOX, and a 25\% Canada supplement for emissions from the ECAR Lite states that pass into Canada as discussed above. The calculation is based on equation 1 . $\mathrm{CO} 2$ is valued at $\$ 10$ per metric tonne. Emissions from average US coal plants in 2004 cause an externality from conventional pollutants exceeding \$26/MWh; with CO2 the total value is $\$ 36 / \mathrm{MWh}$. These are huge costs, since the average industrial price of electricity in the US, which is close to the wholesale price, was $\$ 53 / \mathrm{MWh}$ in 2004 . The average industrial price in ECAR Lite was less than $\$ 45$. For comparison we show a "clean" coal plant with the best 
current SO2 and NOX control technology, whose external costs are $10 \%$ of many of the actual ECAR plants. The total external harm from coal plants in ECAR Lite range from over \$34/MWh in Michigan to over \$51/MWh in Ohio, over half of which is caused by conventional pollutants. In Indiana, Ohio and Kentucky the total external cost exceeds the industrial price of electricity.

The external costs of coal generation in Ontario, based on the Ontario health effects model, are presented for comparison. The external costs are much greater than in any state, $\$ 113 / \mathrm{MWh}$, because of the high exposure-response relationship in the Ontario health effects model. The Ontario electricity price was $\$ 53.10$ in $2004-05$, or $\$ 45.14$ US.

Natural gas emissions and external costs are much lower than those of coal, with the external costs of a typical CCGT generation falling below $\$ 0.50 / \mathrm{MWh}$ for conventional pollutants, but totalling over $\$ 4$ if $\mathrm{CO} 2$ is included. NOX reduction can cut the cost of conventional pollutants to four cents. The average emissions from Indiana gas-fired power plants in 2004 caused harm valued at $\$ 0.69$ per MWh for conventional pollutants and \$7.66 including $\mathrm{CO} 2$. The ECAR gas average total cost was $\$ 6.35$. While gas is a clean fuel compared to coal, the externality is still $15 \%$ of the industrial price of power.

\section{The Under-Pricing of Electricity}

The external costs presented in the first four columns of Table 2 represent the underpricing of power from coal and gas facilities operated by regulated utilities, since they receive an initial distribution of free allowances and thus do not, on average pay for the allowances that they surrender for their air emissions. As noted above, however, a competitive generator will include the opportunity cost of allowances surrendered in calculating its private marginal cost of generation. To calculate the under-pricing for competitive firms, we must subtract from the external costs shown in the "Total" column of Table 2 the cost of allowances surrendered per MWh generated, using 2004 allowance prices, as in equation 2. In 2004, the price of SO2 allowances was about $\$ 260 /$ ton (EPA, 2006), significantly above the average of the preceding few years and rising rapidly in anticipation of CAIR, but still less than $1 / 10^{\text {th }}$ of the externality value of $\$ 3,500$. The price of NOX allowances in the NOX SIP Call region during the ozone season was about $\$ 2,400 /$ ton in 2004 . (US EPA, 2005c, p. 25.) The ozone season is five months, but $1 / 3$ of the annual NOX emissions in 2004 occurred during that season (US EPA, 2005 c, p. 8), so the price of NOX emissions averaged over the entire year's generation was $1 / 3$ of $\$ 2,400$ or $\$ 800 /$ ton, about $3 / 4$ of the externality value of $\$ 1,100$.

The "Competitive Under-pricing" column in Table 2 shows the result. The allowance prices do not reduce the gap between price and full social cost by more than $10 \%$ because SO2 accounts for most of the conventional externality and it was greatly under-priced in the allowance market in 2004. The competitive under-pricing is still $\$ 32$ to $\$ 47$ per MWh for ECAR Lite states, $60 \%$ to $100 \%$ of the average industrial price of electricity in those states. Overall, the under-pricing of coal power is enormous in 2004, primarily because of the failure to price the external harm from $\mathrm{CO} 2$ and the under-pricing of $\mathrm{SO} 2$ emissions.

Pollution and the Price of Power, DRAFT 8

18 July, 2006 
The figures in Table 2 show the under-pricing of electricity from average power plants in various jurisdictions compared to the price that would arise from using an effluent charge to represent full external costs. Without simulating the electricity sector in detail we cannot accurately estimate the impact that correcting this under-pricing would have on the state-wide average market price of power for either regulated or competitive utilities. We can, however, make some back-of-the envelope calculations as suggested in equations 3 and 4.

Ohio used coal to generate about $86.4 \%$ of its electricity in 2004 , while nuclear stations provided $10.8 \%$ and gas $1.13 \%$. See Table 1 . In a regulated state market, $\alpha$ would be 0.864 for coal and 0.0113 for gas. The efficient effluent charge would raise the state-wide average price in 2004 by $0.864 * 51.68+0.0113 * 9.68=\$ 44.76 / \mathrm{MWh}$ according to equation 3 . Indiana, with $94.4 \%$ coal power and $1.91 \%$ gas is similar to Ohio but with higher percentages for both coal and gas. The state-wide under-pricing assuming a regulated market is summarised in Table 3. Across ECAR Lite the average coal percentage is 84.7 , the average gas percentage is 4.03 , so the efficient effluent charge should raise average prices by about $\$ 36.13$. These are still huge price increases, representing between $40 \%$ and $90 \%$ of the 2004 industrial price.

To the extent that generators in these states should be treated as participants in a competitive market the under-pricing calculation is more difficult because it depends on the generation mix across the market, the proportion of time that each unit is a price-setting unit, and the emission rates of individual generation units. We consider both in-state competition and ECAR-wide competition. We assume that nuclear plants are never price-setting, so the fossil plants share the price-setting. In Ohio with the efficient effluent charge raising the cost of generation, the coal plants must be price-setting plants at all but peak times. To be conservative, we assume that they set the price $86.4 \%$ of the time and the gas plants set the price the rest of the time, so the under-pricing would be $0.864 * 47.63+0.136 * 9.00=\$ 42.38 / \mathrm{MWh}$ using equation 4 . We make a similar assumption for the other states except Michigan. In Michigan we assume that coal and gas set the price in proportion to their share of the total market, yielding under-pricing of $\$ 0.82 * 32.04+0.18 * 5.50=\$ 27.27 / \mathrm{MWh}$. Across ECAR the average under-pricing will be $\$ 34.06$. These represent huge price increases.

None of the previous studies found price increases even $1 / 10^{\text {th }}$ this large because they were not addressing this question. Two studies looked at cost increases from a phased-in CAIR program and one looked at an efficient national effluent charge after equilibrium abatement. All omitted CO2 and Canada. None looked at ECAR in isolation.

If an efficient effluent charge had been imposed in ECAR in 2004 so that all generation, regulated or competitive, paid for its external costs, this would have increased electricity prices as indicated above and would have caused a scramble to reduce emissions. This would not be a reasonable policy, however as a modest step in this direction CAIR might have designed with a lower cap and more rapid reductions, to mop up unused allowances.

\section{Reality Check: The Cost of Clean(er) Power}


With the average wholesale price of power in ECAR below $\$ 50$ in 2004, the external costs and under-pricing in Tables 2 and 3 are huge, representing $60 \%$ to $100 \%$ of the wholesale price of power. Even after estimating state-wide average under-pricing, the externalities in Table 3 represent $40 \%$ to $90 \%$ of the price of power. Is it possible that the externalities are so large? We can do a reality check on these calculations by looking to the price premium paid for clean (or "green") power that does not involve air emissions, principally wind power.

The US Department of Energy reports that large scale wind farms can deliver power at a "levelized cost" of 4 to 6 cents/kWh in 2002 \$US. That cost, however, is in class 4 wind power areas which are virtually non-existent in the US east of the Mississippi, except in the middle of the Great Lakes where capital costs would be greater. That cost is exclusive of any subsidies or incentives. (US DOE, 2004, p. 3.) The cost for class 3 sites, which are scattered through the Appalachian Mountains, is 10 to 15 cents $/ \mathrm{kWh}$. This suggests that there is little opportunity for building new wind power in the ECAR region at a cost less than 10 cents $/ \mathrm{kWh}$. The premium over coal power appears to be at least 5 cents per kWh or $\$ 50 / \mathrm{MWh}$.

Palmer and Burtraw (2005) examine the cost of renewable portfolio (RPS) policies in the US, adopted in 16 or more US states, the purpose of which is to promote renewable power in order to reduce the pollution from fossil fuels. Since conventional policies can greatly reduce the emission of conventional pollutants from fossil fuels, the primary benefits of RPS must be GHG reduction. The marginal cost of RPS per ton of carbon dioxide reduced is $\$ 30.25$ at the level of 10\% RPS, and $\$ 34.33$ at 15\% RPS, while a CO2 cap to achieve the same level of CO2 emissions as the $15 \%$ RPS has a marginal welfare cost of $\$ 22.40 /$ ton of CO2. (Palmer and Burtraw, 2005, p. 890.) These costs are similar to our estimates of overall coal under-pricing and are well above the $\$ 10$ per metric tonne for $\mathrm{CO} 2$ emission reduction that we assume.

In Canada, the Ontario Power Authority (OPA/OEB, 2006, p. 21) reports that recent Ontario contracts for the purchase of renewable power, most of which are wind projects, have an average cost of 8.64 cents $\mathrm{CDN} / \mathrm{kWh}$, with the marginal project costing about 9.4 cents. Federal incentives of an additional one cent per kWh are also available. On March 21, 2006, the Ontario Power Authority and the Ontario Energy Board recommended a standard offer for small renewable power contracts at 11 cents/kWh. (OPA/OEB, 2006, p. 21.) The average wholesale cost of power in the first three years of Ontario's electricity market was about 5.5 cents $/ \mathrm{kWh}$, implying a premium of 4 to 6.5 cents per $\mathrm{kWh}(\$ 40$ to $\$ 65 \mathrm{CDN} / \mathrm{MWh})$ for green power.

New York State has been aggressive in limiting emissions from its coal-fired generating stations, with almost $20 \%$ coming from nuclear sources and $17 \%$ from hydroelectric sources, leaving less than $30 \%$ of its power generated from coal, $16.6 \%$ from natural gas, and $17.4 \%$ from oil. See Table 1. This low-coal policy has led to higher cost power, with an industrial price of $\$ 70 / \mathrm{MWh}$, about $\$ 25$ more than the ECAR average despite the moderating influence of large amounts of low-cost hydropower from the Niagara River.

This evidence together suggests that the air pollution benefits of not burning coal or of strictly reducing coal emissions compared to 2004 emission rates must be worth $\$ 40$ to $\$ 50$ per Pollution and the Price of Power, DRAFT 10 18 July, 2006 
MWh or more. It is consistent with the externality and under-pricing values shown in Tables 2 and 3.

This evidence is roughly consistent with the push for renewable power in the US and in Canada, but the incentives created by the existing renewable subsidies and RPS programs are distorting. Because small amounts of costly renewable power are averaged into the price of all power, the high cost of these sources is not visible to consumers. We are building $\$ 100 / \mathrm{MWh}$ generation for consumers who pay \$50. RPS programs do little to discourage the construction of new coal plants, nor to encourage the construction of efficient CCGT plants, or cogeneration plants, so we are not reducing GHG emissions at least cost. Proper pricing of the externality would be a big help in deciding what power to invest in for the future.

\section{External Costs with CAIR}

CAIR is intended to reduce emissions of SO2 and NOX, and the EPA's RIA shows those emissions declining considerably in 2010 and 2015. In the ECAR region, both NOx and SO2 emission rates are reduced by about $2 / 3$ between 2004 and 2015, although the remaining harm is still significant. (EPA 2005a, p. 7-5.) GHG costs per MWh of coal-fired electricity generation do not decline, as no $\mathrm{CO} 2$ control technology is projected to be used.

We utilise the CAIR RIA analysis of emission rates and allowance prices. (US EPA, 2005a, and US EPA, 2005b.) The RIA does not provide emission rates broken down by state and fuel, but it does provide state emission totals by fuel. We assume that coal plants each state in 2015 have the same heat rate as in 2004 and we estimate coal generation by state from the $\mathrm{CO} 2$ emissions. This generation amount then allows us to estimate emission rates for NOX and SO2. The RIA forecasts marginal abatement costs for 2010 and 2015, which should equal the allowance prices in those years. The SO2 marginal cost is $\$ 700 /$ ton in 2010 and $\$ 1,000 /$ ton in 2015; the NOX marginal cost is $\$ 1,300$ and $\$ 1,600 /$ ton respectively. We assume that competitive utilities include these prices in their opportunity cost of generation when determining their marginal cost bids. Regulated utilities, on the other hand, receive a free distribution of allowances and thus, on average, incur no cost to secure their allowances. The under-pricing of electricity is the external cost for regulated utilities and the external cost less the allowance cost for competitive utilities. See Table 4.

Two aspects of the Table 4 calculations are striking. First, while CAIR achieves substantial reductions of conventional emissions from the CAIR states, that reduction is quite varied. By 2015, the coal plants in Ohio are imposing external costs for conventional pollutants of about \$7.50/MWh including the Canada supplement, while the coal plants in Michigan still cause over \$21/MWh of damage. So, in several of the ECAR states, CAIR allows significant damage to continue a decade after the initiation of the regulation.

Second, the total external cost when $\mathrm{CO} 2$ is included is still considerable for the average coal plant in most ECAR states. In Indiana and Kentucky, the total with CO2 is over \$20/MWh, while Michigan is over $\$ 30$. Across ECAR, the average external cost is between $\$ 15$ and Pollution and the Price of Power, DRAFT 11

18 July, 2006 
\$30/MWh. The external cost equals the under-pricing for regulated utilities and the underpricing for competitive utilities is only modestly better because there is no trading program for CO2. Coal power is greatly under-priced in 2015 even with CAIR. This is a dramatic contrast to the effect of an efficient effluent charge, simulated by Banzhaf et al. (2005). They estimate that $\mathrm{SO} 2$ emissions would be reduced by $89 \%$ and NOX emissions by $70 \%$ with an efficient charge, much larger reductions than the $2 / 3$ reductions forecast for CAIR by 2015 .

Even Table 4 must overstate the effect of an efficient effluent charge in ECAR because, as Banzhaf et al. report, further emission reductions would occur. Suppose that the efficient charge led to all coal plants achieving the emission rates of the "clean coal" plant in Table 2, which has flue gas desulphurisation, selective catalytic reduction, and an electrostatic precipitator. Suppose that all gas consumption was in CCGT plants similar to the "New CCGT" in Table 2. In this case, the external costs of pollutants would be very low, $\$ 13$ for coal and $\$ 3.60$ for gas, and dominated by the costs associated with CO2. Such a charge with such low emission rates would raise prices, but as in the previous calculations, by less than these amounts. These amounts are still more than suggested in any of the major simulations because we have included $\mathrm{CO} 2$.

The efficient cap-and-trade policy or effluent charge policy will increase pollution control costs while it reduces external costs. Banzhaf et al. (2004, p. 333) estimate that a $\$ 3,500 /$ ton SO2 charge will lead to abatement expenditures of $\$ 7.48$ billion/year beyond baseline for $\mathrm{SO} 2$, which, if allocated to all coal-fired power $(2,113$ million $\mathrm{MWh})$ costs $\$ 3.54 / \mathrm{MWh}$. Allocating NOX costs of $\$ 4.36$ billion to coal plus gas-fired power (2,999 million MWh) costs $\$ 1.45 / \mathrm{MWh}$; if these costs were incurred predominantly in coal-fired power plants, the cost would be $\$ 2.06 / \mathrm{MWh}$. The total cost increase for pollution control in coal plants in ECAR would be about $\$ 5 / \mathrm{MWh}$, or $10 \%$. This is almost double the EPA's estimate that CAIR would impose retail cost increases of 5.9\% in ECAR. (EPA, 2005a, p. 7-14.) This still leaves the under-pricing discussed above.

\section{Conclusions}

US air pollution control policy has succeeded in gradually reducing the emissions of $\mathrm{SO} 2$ and NOX, especially from large power plants. The NOX SIP Call and CAIR will continue to reduce those emissions. Cap-and-trade programs have minimised the cost of these achievements. Studies have shown that these policies will raise electricity prices only modestly and will not significantly alter the fuel mix. Yet the widely-accepted data on the harm from these pollution emissions suggest that electricity has been seriously under-priced in regions relying primarily on coal, particularly the ECAR region around the Great Lakes. Here coal power should, in 2004, have cost about $\$ 40$ per MWh more than the actual price. This externality is worth more than the market price of the coal that creates it. The average price of electricity in ECAR, including coal-fired and other plants was about $\$ 35$ too low. Correcting this under-pricing would increase the wholesale price of power by more than $60 \%$. The underpricing will still be significant with CAIR a decade from now, perhaps as much as $\$ 15$ to $\$ 30$ per 
MWh for coal. So long as coal retains its dominance in this area, electricity consumers in the Great Lakes region, principally in ECAR, should pay much more for their electricity.

There are four principal reasons for the under-pricing. First, SO2 allowance prices have been far below the estimated damage caused by the pollutants and some of that deficiency will remain in 2015. While there is much to admire in the existing emissions trading programs, the caps appear not to be sufficiently rigorous. Second, since allowances are distributed at no charge, the opportunity cost of those allowances does not show up as a cost to the average regulated utility, which sells as many allowances as it purchases. In consequence, regulated prices, on average, do not include the price of all allowances retired and thus the environmental damage caused by their remaining pollution. This is an efficiency cost of the free distribution of allowances. Third, and in the long run most important, $\mathrm{CO} 2$ discharge is neither regulated nor subject to emissions trading, despite the general agreement in the literature that the social cost of $\mathrm{CO} 2$ discharge is considerable. Fourth, for states south of the Great Lakes the benefits to Canada from emission reductions are completely ignored in US policy analysis and development.

Does the relatively inelastic demand for electricity render this under-pricing irrelevant? There are several arguments that getting the prices right would make a difference. First, policies that imposed higher cost on polluting sources would speed up the reduction of emissions through the installation of scrubbers and catalysts and through the dispatch of low-emission units before high-emission units. Second, higher electricity prices of the magnitudes discussed here would induce significant conservation by all classes of consumers. Third, a price for $\mathrm{CO} 2$ emissions from coal-fired power plants would allow a market test of the economic attractiveness of clean coal technologies such as integrated coal gasification and generation with carbon sequestration. Fourth, higher power prices would facilitate investment in renewable power plants. If we get the prices right, then the market can more convincingly choose the best sources of new generation for the next decades. 


\begin{tabular}{|l|r|r|r|r|}
\hline \multicolumn{5}{|c|}{$\begin{array}{c}\text { Table 1 } \\
\text { Generation Mix: 2004 } \\
\text { (\%) }\end{array}$} \\
\hline & \multicolumn{1}{|c|}{ Coal } & \multicolumn{1}{c|}{ Oil } & \multicolumn{1}{c|}{ Gases } & \multicolumn{1}{c|}{ Nuclear } \\
\hline Michigan & 57.9 & 0.75 & 12.78 & 25.8 \\
\hline Indiana & 94.4 & 0.35 & 4.35 & 0 \\
\hline Ohio & 86.4 & 0.94 & 1.13 & 10.8 \\
\hline Kentucky & 91.1 & 3.83 & 0.61 & 0 \\
\hline West Virginia & 97.6 & 0.30 & 0.44 & 0 \\
\hline ECAR Lite Average & 84.7 & 1.14 & 4.03 & 8.02 \\
\hline New York & 29.5 & 17.4 & 16.6 & $19.8^{*}$ \\
\hline Ontario (2004) & 17 & & & $49^{*}$ \\
\hline & & & & \\
\hline
\end{tabular}

US data from US DOE EIA (2005, EIA 906).

Ontario data from Ontario Ministry of the Energy website, accessed February, 2006:

http://www.energy.gov.on.ca/index.cfm?fuseaction=english.electricity .

* New York hydroelectric $-17.4 \%$; Ontario hydroelectric $=25 \%$. 


\begin{tabular}{|l|l|r|r|r|r|r|}
\hline \multicolumn{7}{|c|}{ Table 2 } \\
\multicolumn{7}{|c|}{ Generation Plant External Costs, Under-Pricing: 2004} \\
(\$US/MWh)
\end{tabular}

1. US DOE industrial price: $\mathrm{http}$ ://www.eia.doe.gov/cneaf/electricity/esr/figure7 7.html .

\begin{tabular}{|l|c|c|c|c|c|c|}
\hline \multicolumn{7}{|c|}{ Table 3 } \\
\multicolumn{7}{|c|}{ State/Regional Under-Pricing All Fuels: 2004 } \\
\hline & Coal & Gas & Regulated & Coal & Gas & Competitive \\
\hline & $\boldsymbol{\alpha}$ & $\boldsymbol{\alpha}$ & \$US/MWh & $\boldsymbol{\beta}$ & $\boldsymbol{\beta}$ & \$US/MWh \\
\hline Michigan & 0.579 & 0.1278 & 20.86 & 0.820 & 0.180 & 27.27 \\
\hline Indiana & 0.944 & 0.0435 & 41.94 & 0.944 & 0.056 & 38.79 \\
\hline Ohio & 0.864 & 0.0113 & 44.76 & 0.864 & 0.136 & 42.38 \\
\hline Kentucky & 0.911 & 0.0061 & 34.63 & 0.911 & 0.089 & 32.60 \\
\hline West Virginia & 0.976 & 0.0044 & 35.72 & 0.976 & 0.024 & 32.73 \\
\hline ECAR Lite Average & $\mathbf{0 . 8 4 7}$ & $\mathbf{0 . 0 4 0 3}$ & $\mathbf{3 6 . 1 3}$ & $\mathbf{0 . 8 5 0}$ & $\mathbf{0 . 1 5 0}$ & $\mathbf{3 4 . 0 6}$ \\
\hline & & & & & & \\
\hline
\end{tabular}

From equations 3, 4, based on unit under-pricing in Table 2. 


\begin{tabular}{|c|c|c|c|c|c|}
\hline \multicolumn{6}{|c|}{$\begin{array}{c}\text { Table } 4 \\
\text { Generation Plant External Costs, Under-Pricing: CAIR } 2015 \\
\left(\$ \mathrm{SS}^{\mathrm{M} W \mathrm{M})}\right)\end{array}$} \\
\hline Plant & $\begin{array}{l}\text { SO2 and } \\
\text { NOX }\end{array}$ & $\begin{array}{l}\text { CDN } \\
\text { Supp }\end{array}$ & $\mathrm{CO} 2$ & $\begin{array}{c}\text { Total } \\
\text { (Regulated under- } \\
\text { pricing) }\end{array}$ & $\begin{array}{l}\text { Competitive } \\
\text { Under-pricing }\end{array}$ \\
\hline \multicolumn{6}{|l|}{ Coal } \\
\hline & & & & & \\
\hline Clean & 2.87 & NA & 10.00 & 12.87 & 12.68 \\
\hline Michigan & 17.33 & 4.33 & 9.79 & 31.45 & 25.19 \\
\hline Indiana & 9.95 & 2.49 & 9.66 & 22.10 & 18.48 \\
\hline Ohio & 5.98 & 1.50 & 9.46 & 16.94 & 14.54 \\
\hline Kentucky & 9.94 & 2.48 & 9.60 & 22.02 & 18.22 \\
\hline West Va. & 4.28 & 1.07 & 9.29 & 14.64 & 12.89 \\
\hline ECAR Lite Avg & 8.94 & 2.23 & 9.55 & 20.72 & 17.35 \\
\hline & & & & & \\
\hline
\end{tabular}




\section{References}

Banzhaf, Spencer, Dallas Burtraw, and Karen Palmer, 2004, "Efficient Emission Fees in the US Electricity Sector", Resource and Energy Economics, 26(217-241).

Burtraw, Dallas, Karen Palmer, Karen and Alan J. Krupnik, 1997, "Second-Best Adjustments to Externality Estimates in Electricity Planning with Decomposition," Land Economics, 73(2), 22439.

Canada, 2005, Elements of the Plan, Government of Canada, http://climatechange.gc.ca/kyoto_commitments/c3 e.pdf, viewed January 12, 2006.

Dewees, Donald N., 2006, "Electricity Restructuring in the Provinces: Ontario and Beyond", University of Toronto, Department of Economics Working Paper TECIPA 205, http://repec.economics.utoronto.ca/files/tecipa-205-1.pdf.

DSS, RWDI, 2005, “Cost-Benefit Analysis: Replacing Ontario’s Coal-Fired Electricity Generation," Report submitted to the Ontario Ministry of Energy, April, 2005, http://www.energy.gov.on.ca/english/pdf/electricity/coal cost benefit analysis april2005.pdf, viewed December, 2005.

Evolution Markets, 2006, "Emissions Markets: Weekly Market Update” Friday, 24 March 2006, SO2 spot, NOX spot. http://www.evomarkets.com/reports/weekly/emissions/060324 wkmk emis.html Accessed 28 March, 2006.

Evolution Markets, 2006, "Greenhouse Gas Emissions Markets: Weekly Market Update” Friday, 24 March 2006, EU CO2.

http://www.evomarkets.com/reports/weekly/ghg/060320_wkmk_ghg.html . Accessed 28 March, 2006.

Gillingham, Kenneth, Richard G. Newell, and Karen Palmer, 2004, "Retrospective Examination of Demand-Side Energy Efficiency Policies," RFF Discussion Paper DP 04-19, Sept., 2004 : Washington, D.C. http://www.rff.org/rff/Documents/RFF-DP-04-19REV.pdf, May 28, 2006.

Joskow, Paul L. and Richard Schmalensee, 1983, Markets for Power: An Analysis of Electric Utility Deregulation, Cambridge: MIT Press.

Joskow, Paul L., 2006, "Markets for Power in the United States: An Interim Assessment", The Energy Journal 27:1, pp. 1-36.

Klepper, Gernot and Sonja Peterson, 2006, "Emissions Trading, CDM, JI, and More: The Climate Strategy of the EU", The Energy Journal, 27:2, 2006, pp. 1-26. 
National Commission on Energy Policy, 2004, "Ending the Energy Stalemate", www.energycommission.org, Accessed March 22, 2006.

Neuhoff, Karsten, Michael Grubb, Kim Keats, 2005, "Impact of the Allowance Allocation on Prices and Efficiency", CWPE WP 0552 and EPRG 08.

Ontario Clean Air Alliance, 2005, "A New Electricity Strategy for Ontario", OCAA, Toronto. Available at: http://www.cleanair.web.ca/resource/newstrategyfinal.pdf . (March, 2006)

Ontario Power Authority, Ontario Energy Board, 2006, "Joint Report to the Minister of Energy: Recommendations on a Standard Offer Program for Small Generators Connected to a Distribution System", http://www.oeb.gov.on.ca/documents/cases/EB-20050463/standard_reportominister_210306.pdf, March 17, 2006, accessed 23 March, 2006.

Ontario Power Generation, 2003, "Towards Sustainable Development: 2002 Progress Report", OPG: Toronto.

Palmer, Karen and Dallas Burtraw, 2005, "Cost-Effectiveness of Renewable Electricity Policies”, Energy Economics, 27, pp. 873-894.

Palmer, Karen, Dallas Burtraw and Jhih-Shyang Shih, 2005, "Reducing Emissions from the Electricity Sector," Resources for the Future, Discussion Paper 05-23, Washington, RFF.

Pearce, D.W., W.R. Cline, A.N. Achanta, S. Fankhauser, R.K. Pachauri, R.S.J. Tol, P. Vellinga, 1996, "The Social Costs of Climate Change: Greenhouse Damage and the Benefits of Control", chapter 6 in Climate Change 1995: Economic and Social Dimensions of Climate Change, James P. Bruce, Hoesung Lee, Eric F. Haites, eds, IPCC, Cambridge University Press, Cambridge.

RFF, 2003, The RFF Guide to Climate Change Economics and Policy, Washington D.C., Resources for the Future.

RGGI, Regional Greenhouse Gas Initiative, 2005, "RGGI Package Scenario" http://www.rggi.org/documents.htm, accessed 22 March, 2006.

Tol, Richard S. J., 1999, “The Marginal Costs of Greenhouse Gas Emissions”, The Energy Journal 20:1, 61-81.

US Department of Energy, 2004, Energy Efficiency and Renewable Energy Program, 2004, "Wind Power Today \& Tomorrow," March. http://www.nrel.gov . Accessed 23 March, 2006.

US Department of Energy, Energy Information Administration, 2005, "1990 - 2004 Net Generation by State by Type of Producer by Energy Source (EIA-906)," and "1990-2004 U.S. Electric Power Industry Estimated Emissions by State (EIA-767 and EIA-906)," http://www.eia.doe.gov/cneaf/electricity/epa/epa_sprdshts.html, Accessed May, 2006. 
US Environmental Protection Agency, 2005a, Regulatory Impact Analysis for the Final Clean Air Interstate Rule, Office of Air and Radiation, EPA-452/R-05-002, March, 2005, Washington D.C., http://www.epa.gov/cair/technical.html\#final , accessed April 3, 2006.

US Environmental Protection Agency, 2005b, Regulatory Impact Analysis for the Final Clean Air Interstate Rule, IPM Parsed File EPA Final CAIR parsed for year 2015 (Final CAIR modeling), at http://www.epa.gov/airmarkets/epa-ipm/iaqr.html , accessed April 3, 2006.

US EPA, 2005c, Evaluating Ozone Control Programs in the Eastern United States: Focus on the NOX Budget Trading Program, 2004,” EPA 454-K-05-001, August, 2005, Washington, D.C., http://www.epa.gov/airtrends/2005/ozonenbp.pdf, accessed April 11, 2006.

US EPA, 2006, "2004 Acid Rain SO2 Allowance Auction”, http:/www.epa.gov/airmarkets/auctions/2004/index.html, accessed April 11, 2006.

Varian, Hal R., 1990, Intermediate Microeconomics: a Modern Approach, $2^{\text {nd }}$ edn., WW Norton: New York. 